Corresponding authors: j.ware@ imperial.ac.uk, stuart.cook@nhcs. com.sg

(C) 2017 Rea et al. This article is distributed under the terms of the Creative Commons Attribution License, which permits unrestricted reuse and redistribution provided that the original author and source are credited.

Ontology terms: asymmetric, linear skin defects; dilated cardiomyopathy; left ventricular noncompaction cardiomyopathy; linear hyperpigmentation; microphthalmos; oncocytic cardiomyopathy; ventricular fibrillation; Wolff-ParkinsonWhite syndrome

Published by Cold Spring Harbor Laboratory Press

doi: 10.1101/mcs.a001271

\section{Histiocytoid cardiomyopathy and microphthalmia with linear skin defects syndrome: phenotypes linked by truncating variants in NDUFB11}

\author{
Gillian Rea, ${ }^{1,2,3}$ Tessa Homfray, ${ }^{4}$ Jan Till, ${ }^{4}$ Ferran Roses-Noguer, ${ }^{4}$ \\ Rachel J. Buchan, ${ }^{1,2}$ Sam Wilkinson, ${ }^{1,2}$ Alicja Wilk, ${ }^{1,2}$ Roddy Walsh, ${ }^{1,2}$ \\ Shibu John, ${ }^{1,2}$ Shane McKee, ${ }^{3}$ Fiona J. Stewart, ${ }^{3}$ Victoria Murday, ${ }^{5}$ \\ Robert W. Taylor, ${ }^{6}$ Michael Ashworth, ${ }^{7}$ A. John Baksi, ${ }^{4}$ Piers Daubeney, ${ }^{2,4}$ \\ Sanjay Prasad, ${ }^{1,4}$ Paul J.R. Barton, ${ }^{1,2}$ Stuart A. Cook, ${ }^{2,8,9,10}$ \\ and James S. Ware ${ }^{1,2,8,10}$
}

\begin{abstract}
${ }^{1}$ NIHR Cardiovascular Biomedical Research Unit at Royal Brompton and Harefield NHS Foundation Trust and Imperial College London, London SW3 6NP, United Kingdom; ${ }^{2}$ National Heart and Lung Institute, Imperial College London, London SW3 6NP, United Kingdom; ${ }^{3}$ Northern Ireland Regional Genetics Service, Belfast City Hospital, Belfast, BT9 7AB, United Kingdom; ${ }^{4}$ Royal Brompton and Harefield NHS Foundation Trust, London SW3 6NP, United Kingdom; ${ }^{5}$ Department of Clinical Genetics, Laboratory Medicine, The Queen Elizabeth University Hospital, Glasgow G51 4TF, United Kingdom; ${ }^{6}$ Wellcome Trust Centre for Mitochondrial Research, Institute of Neuroscience, Newcastle University, Newcastle upon Tyne, NE2 4HH, United Kingdom; ${ }^{7}$ Histopathology Department, Camelia Botnar Laboratories, Great Ormond Street Hospital for Children NHS Trust, London WC1N 3JH, United Kingdom; ${ }^{8}$ MRC Clinical Sciences Centre, Imperial College London, London W12 ONN, United Kingdom; ${ }^{9}$ National Heart Centre Singapore, Singapore 169609, Singapore
\end{abstract}

Abstract Variants in NDUFB11, which encodes a structural component of complex I of the mitochondrial respiratory chain (MRC), were recently independently reported to cause histiocytoid cardiomyopathy (histiocytoid CM) and microphthalmia with linear skin defects syndrome (MLS syndrome). Here we report an additional case of histiocytoid CM, which carries a de novo nonsense variant in NDUFB11 (ENST00000276062.8: c.262C > T; p.[Arg88*]) identified using whole-exome sequencing (WES) of a family trio. An identical variant has been previously reported in association with MLS syndrome. The case we describe here lacked the diagnostic features of MLS syndrome, but a detailed clinical comparison of the two cases revealed significant phenotypic overlap. Heterozygous variants in HCCS (which encodes an important mitochondrially targeted protein) and COX7B, which, like NDUFB11, encodes a protein of the MRC, have also previously been identified in MLS syndrome including a case with features of both MLS syndrome and histiocytoid CM. However, a systematic review of WES data from previously published histiocytoid CM cases, alongside four additional cases presented here for the first time, did not identify any variants in these genes. We conclude that NDUFB11 variants play a role in the pathogenesis of both histiocytoid CM and MLS and that these disorders are allelic (genetically related). 


\section{INTRODUCTION}

NDUFB11 (OMIM *300403) variants have recently been independently proposed to cause histiocytoid cardiomyopathy (histiocytoid CM; OMIM 500000) (Shehata et al. 2015) and microphthalmia with linear skin defects syndrome (MLS; OMIM 309801) (van Rahden et al. 2015). Histiocytoid CM is a rare, distinctive form of cardiomyopathy with approximately 150 cases reported worldwide, it has numerous synonyms including oncocytic cardiomyopathy (Shehata et al. 2011). Predominantly affecting females early in life, it is characterized by arrhythmias and associated sudden death (Gilbert-Barness and Barness 2006). Associated cardiac abnormalities include ventricular and atrial septal defects, endocardial fibroelastosis, and hypoplastic left heart syndrome (Shehata et al. 1998). Extracardiac features involving the nervous system and eyes are also frequently reported (Malhotra et al. 1994). Variants in mitochondrial DNA (mtDNA) have previously been associated with histiocytoid CM (Vallance et al. 2004), but this has not been replicated in further studies. Histological findings in cardiac tissue often show an accumulation of excessive, aberrantly shaped mitochondria, supporting the role of mitochondrial dysfunction in the etiology (Shehata et al. 2015).

MLS syndrome, also known as MIDAS syndrome (microphthalmia, dermal aplasia, and sclerocornea) (Happle et al. 1993), was first described in 1988 (Al-Gazali et al. 1988). It is a rare X-linked disorder with male lethality in utero, characterized by unilateral or bilateral microphthalmia and linear skin defects. Skin defects are classically limited to the face and neck along Blaschko's lines, are present from birth, and heal with time, often leaving minimal scarring. Additional clinical features may include neurological and cardiac abnormalities (Morleo and Franco 1993). Heterozygous variants in the X-encoded genes HCCS (OMIM *300056) (Wimplinger et al. 2006), which encodes an important mitochondrially targeted protein, and COX7B (OMIM *300885) (Indrieri et al. 2012), which encodes a component of the mitochondrial respiratory chain (MRC), have been identified previously in MLSaffected females (Indrieri et al. 2012). However, variants are not detected in all cases, suggesting genetic heterogeneity.

More than 20 years ago, Bird and coworkers reported an infant with the characteristic skin lesions of the then newly recognized MLS syndrome and a normal 46, XX karyotype, who died suddenly and unexpectedly at 4 mo of age. Death was attributed to oncocytic (histiocytoid) cardiomyopathy (Bird et al. 1994). The authors noted that the "coexistence of two rare conditions, one of which mapped to the X Chromosome, and an excess of affected females with oncocytic cardiomyopathy, make it likely that oncocytic cardiomyopathy is also Xlinked, with Xp22 being a candidate region. Overlapping manifestations in the two conditions (ocular abnormalities in cases of oncocytic cardiomyopathy and arrhythmias in MLS) offer additional support for this hypothesis" (Bird et al. 1994). Here, we present evidence in support of the allelic nature of these conditions. We describe a new case of histiocytoid CM in whom we identified a de novo nonsense variant in NDUFB11 (c.262C > T; p.(Arg88*)) (see Table 1). An identical variant has recently been reported as the molecular basis of a case of MLS syndrome. We compare the clinical features of these cases (see Table 2), highlighting that although each of the two entities show distinct manifestations, they share substantial phenotypic overlap and potential mechanisms are outlined.

\section{RESULTS}

The trio sequencing approach identified two rare de novo variants, predicted to be protein altering in the proband: NDUFB11 c.262C > T; p.(Arg88*) and FAM135A c.474C > G; p.(Tyr158*). Sanger sequencing confirmed the presence of both variants in the affected child and their absence in the unaffected parents (see Fig. 1). NDUFB11 was a highly 


\begin{tabular}{ll}
\hline Table 1. Summary of variant of interest in NDUFB11 & \\
\hline HGNC symbol & NDUFB11 \\
Name & NADH:ubiquinone oxidoreductase subunit B11 \\
Genomic location & Chromosome X: 47002089 \\
GRCh37 (hg19) & \\
HGVS cDNA & ENST00000276062.8 c.262C > T \\
HGVS protein & p.(Arg88*) \\
Predicted effect & Stop gained \\
Genotype & Heterozygous \\
Inheritance mode & Sporadic \\
Frequency in ExAC & 0 \\
\hline
\end{tabular}

HGNC, HUGO Gene Nomenclature Committee; HGVS, Human Genome Variation Society; ExAC, Exome Aggregation Consortium.

plausible candidate gene, located on the X Chromosome, providing a potential mechanism for the predominance of females affected (with presumed in utero male lethality), with a mitochondrial function in keeping with previous understanding of histiocytoid CM as a mitochondrial disorder. Alternative inheritance models (monoallelic or biallelic) were considered with no additional strong candidate genes identified. We interrogated four additional unrelated cases of histiocytoid CM for variants in NDUFB11, COX7B, or HCCS, and no putative disease-causing variation was identified. We also reviewed publicly available WES data (Shehata et al. 2015) from three additional cases of histiocytoid CM without NDUFB11 variants and found no evidence of de novo or rare variants in either HCCS or COX7B.

\section{DISCUSSION}

At the outset of our study the molecular etiology of histiocytoid CM was unknown; we undertook WES in a trio involving an affected child (see Fig. 2) and both unaffected parents. This identified a de novo nonsense variant in NDUFB11, an X-encoded mitochondrial gene, consistent with the suspected role of mitochondrial dysfunction in histiocytoid CM (Ferrans et al. 1976) and a de novo nonsense variant in FAM135A.

Simultaneous to our analyses, two independent reports showed evidence of variants in NDUFB11 associated with histiocytoid CM (Shehata et al. 2015) and MLS syndrome (van Rahden et al. 2015). The phenotypic associations of these additional variants in NDUFB11 and ours are shown in Table 3. An identical variant to that reported here has recently been reported in a case of MLS in whom histiocytoid CM was found postmortem (van Rahden et al. 2015) indicating a shared molecular basis for these conditions. Our case lacked the diagnostic features of MLS syndrome (see Table 2). Although FAM135A was not formally excluded as a candidate, there was no additional evidence to implicate a role for it in histiocytoid CM.

Seventy five percent of cases of histiocytoid CM present in female infants (Shehata et al. 2015), often below 2 yr of age (Gilbert-Barness and Barness 2006), and the identification of NDUFB11, found on Xp11.23, as an underlying cause explains the large excess of affected females. There have been no molecular reports yet to confirm this as a cause of embryonic male lethality, although Shehata and coworkers comment it is "tempting to speculate that similar mutations occurring in males are embryonic lethal and cause miscarriage, since there would be no residual protein activity" (Shehata et al. 2015). 
Table 2. Detailed comparison of the clinical features of two individuals with the same NDUFB11 truncating variant (ENST00000276062.8: c.262C > T; p. (Arg88*))—one manifesting primarily as histiocytoid CM, the other with microphthalmia and linear skin defects syndrome

\begin{tabular}{|c|c|c|}
\hline Phenotypic feature & Case described here (Case 1) & $\begin{array}{c}\text { Case reported by } \\
\text { van Rahden et al. } 2015\end{array}$ \\
\hline Presenting phenotype & Histiocytoid CM & $\begin{array}{l}\text { Microphthalmia and linear skin } \\
\text { defects syndrome }\end{array}$ \\
\hline \multirow[t]{2}{*}{ Antenatal history } & Healthy, nonconsanguineous parents & Healthy, nonconsanguineous parents \\
\hline & $\begin{array}{l}\text { Alternating bradycardia and } \\
\text { tachycardia noted at } 27 \mathrm{wk} \text {; } \\
\text { emergency Cesarean section at } 38 \\
\text { wk for fetal tachycardia }\end{array}$ & \\
\hline Sex & Female & Female \\
\hline Birth weight & $3690 \mathrm{~g}$ (91st centile) & $3060 \mathrm{~g}$ (10th-25th centile) \\
\hline Cardiac arrhythmias & $\begin{array}{l}\text { Neonatal episodes of supraventricular } \\
\text { tachycardia; collapse with first } \\
\text { documented ventricular tachycardia } \\
\text { (VT) at } 7 \text { mo; continued VT } \\
\text { "storms" necessitating drug } \\
\text { treatment, dual chamber } \\
\text { implantable cardiac defibrillator, } \\
\text { and left thoracic sympathectomy; } \\
\text { cardiac transplantation was carried } \\
\text { out at } 13 \text { mo }\end{array}$ & $\begin{array}{l}\text { Sudden unexpected cardiac arrest } \\
\text { aged } 6 \text { mo; repeated treatment for } \\
\text { ventricular arrhythmias; death within } \\
\text { several weeks }\end{array}$ \\
\hline Cardiomyopathy & $\begin{array}{l}\text { Features of left ventricular } \\
\text { noncompaction; preserved systolic } \\
\text { function }\end{array}$ & Nil reported \\
\hline Cardiac histology & Histiocytoid CM & Histiocytoid CM \\
\hline \multicolumn{3}{|l|}{ Eye abnormalities } \\
\hline Microphthalmia & Not present & Nil reported \\
\hline Scleroderma & Not present & Nil reported \\
\hline $\begin{array}{l}\text { Other eye } \\
\text { abnormalities }\end{array}$ & Intermittent squint & Lacrymal duct atresia \\
\hline Neuromuscular & Mild-to-moderate bulbar palsy & Axial hypotonia present from birth \\
\hline Skin abnormalities & None present & $\begin{array}{l}\text { Linear skin defects on nose, chin, and } \\
\text { neck present at birth, disappeared } \\
\text { in the first few months of life }\end{array}$ \\
\hline Thyroid abnormalities & $\begin{array}{l}\text { Focal histiocytoid change in the } \\
\text { thyroid (and also lungs and choroid } \\
\text { plexus of the brain) }\end{array}$ & $\begin{array}{l}\text { Oncocytic metaplasia evidence on } \\
\text { postmortem }\end{array}$ \\
\hline Other anomalies & $\begin{array}{l}\text { Severe feeding difficulties } \\
\text { gastroesophageal reflux, requiring } \\
\text { Nissen fundoplication and } \\
\text { percutaneous endoscopic } \\
\text { gastrostomy }\end{array}$ & $\begin{array}{l}\text { Failure to thrive documented from } 1 \\
\text { mo of age }\end{array}$ \\
\hline $\begin{array}{l}\text { Evidence of somatic } \\
\text { mosaicism }\end{array}$ & $\begin{array}{l}\text { No evidence in DNA from } \\
\text { lymphocytes }\end{array}$ & $\begin{array}{l}\text { Yes, in DNA from lymphocytes and } \\
\text { fibroblasts }\end{array}$ \\
\hline
\end{tabular}

$\mathrm{CM}$, cardiomyopathy.

There is evidence for genetic heterogeneity in histiocytoid CM, as variants in NDUFB11 and other candidate genes described here do not explain all cases. We hypothesize that HCCS (OMIM 30056) and COX7B (OMIM 300885), which are X-linked genes encoding or targeting mitochondrial proteins and are implicated in MLS, are good candidate genes for 


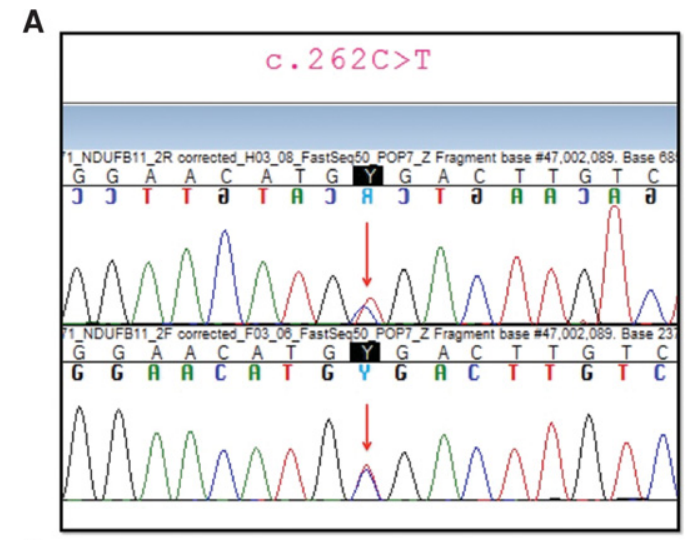

B

C
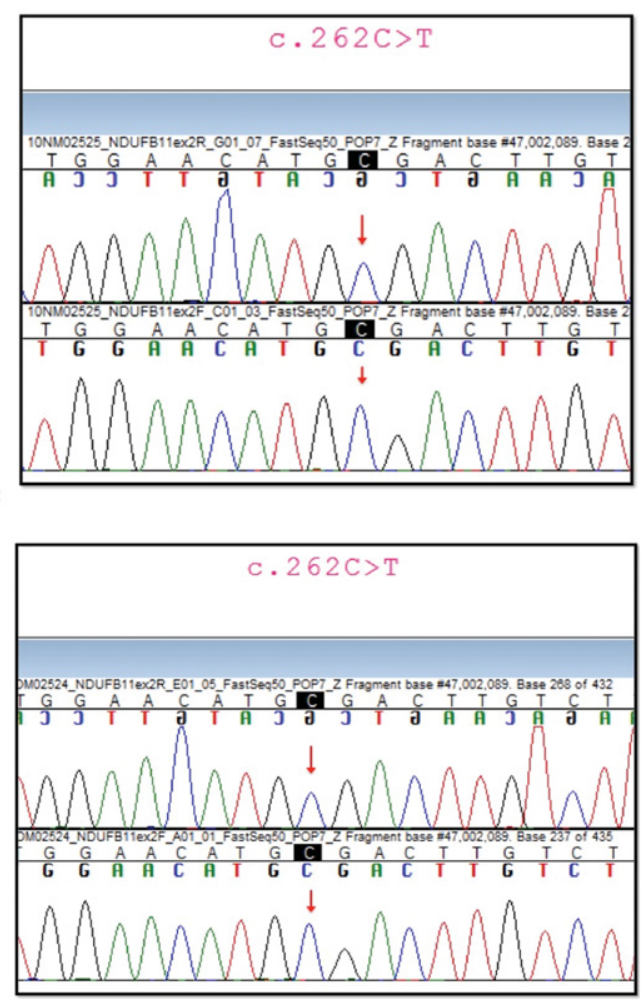

Figure 1. (A) Sequence electropherogram from genomic DNA of child affected by histiocytoid cardiomyopathy (CM) from the family trio showing the NDUFB11 variant identified by whole-exome sequencing (WES) and confirmed by Sanger sequencing. The image shows part of NDUFB11 exon 2. Forward and reverse reads are shown. The red arrows point to the double peak in the electropherogram showing heterozygosity for the nonsense variant in NDUFB11 c. $262 \mathrm{C}>\mathrm{T}$. The next-generation sequencing (NGS) coverage at this base was 62x, with 27 reference reads and 33 alternate reads. (B) Sequence electropherogram from genomic DNA of the unaffected mother from the trio showing no evidence of the NDUFB11 sequence-level variant that had been identified in the affected child. The image shows part of NDUFB11 exon 2. Forward and reverse reads are shown. The red arrows point to the base where the nonsense variant in NDUFB11 c.262C $>$ T was detected in the affected daughter. The coverage at this base on WES was 50x, with no evidence of the variant. (C) Sequence electropherogram from genomic DNA of the unaffected father from the trio showing no evidence of the NDUFB11 variant that was identified in the affected child. The image shows part of NDUFB11 exon 2. Forward and reverse reads shown. The red arrows point to the base where the nonsense variant in NDUFB11 c.262C > T was detected in the affected daughter. The coverage at this base on WES was $26 \times$, with no evidence of the variant. 
COLD SPRING HARBOR Molecular Case Studies
The genetic basis of histiocytoid cardiomyopathy

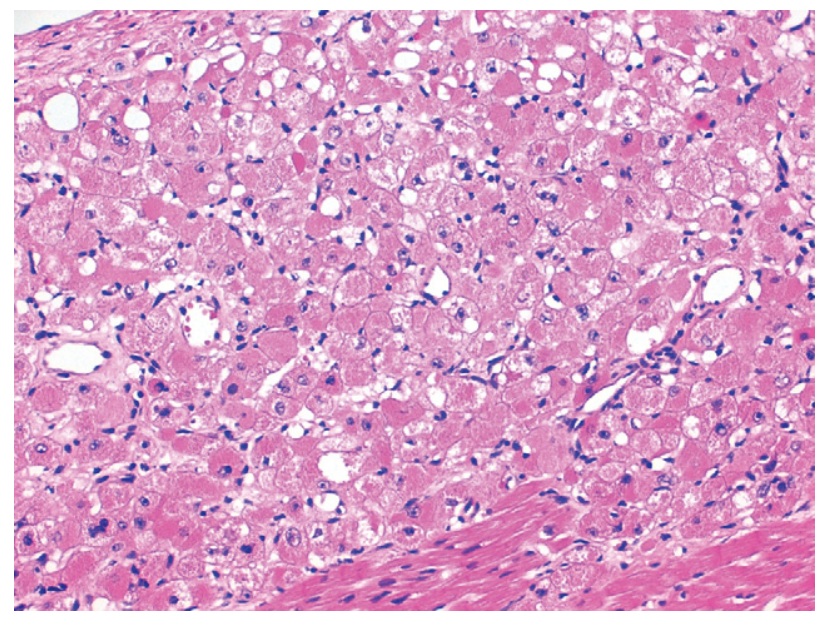

Figure 2. Histology of histiocytoid cardiomyopathy. Longitudinal section of myocardium from an infant with histiocytoid cardiomyopathy. A few normal myocytes are present in the lower part of the field. The remaining cells are histiocytoid myocytes.

histiocytoid CM. We note that van Rahden et al. (2014) have reported previously a female child with a de novo HCCS nonsense variant (c.589C > T; p.(R197*)) and extremely skewed X-inactivation (98:2) with classical features of MLS including linear skin defects on her neck, microphthalmia, anophthalmia, and sclerocornea, who died at 4 mo with ventricular tachycardia (VT) and was found to have histiocytoid CM on postmortem examination, further supporting that MLS and histiocytoid CM are allelic disorders. However, no rare variants were found in HCCS or COX7B in seven additional histiocytoid CM cases without NDUFB11 variants (four described here, three in Shehata et al. 2015), though this small series does not exclude a role in "isolated" histiocytoid CM.

Comparisons (see Table 2) between the phenotype in the case of histiocytoid CM presented here and the case of MLS with an identical NDUFB11 variant (van Rahden et al. 2015) show considerable phenotypic overlap. The case of MLS also had histiocytoid CM; a feature only identified on postmortem examination. The vast majority of cases of histiocytoid $\mathrm{CM}$ are identified postmortem or on examination of the native explanted heart during cardiac transplantation. It is possible that additional cases of MLS also have histiocytoid CM but it remains undetected, as has previously been reported (Bird et al. 1994). Previously there was no specific clinical indication to perform detailed cardiac phenotyping in MLS and so further data are lacking. Wimplinger et al. 2006 reported a female, born to healthy nonconsanguineous parents after an uneventful pregnancy, found to have bilateral microphthalmia and sclerocornea but no erythematous skin lesions. She had a de novo HCCS nonsense variant (c.589C > T; p.(R197*)) that was also reported in an additional case with both MLS and histiocytoid CM (van Rahden et al. 2014). Around 1 yr of age she was reported to have developed "idiopathic VT" (Wimplinger et al. 2006). In the absence of cardiac histology a diagnosis of histiocytoid CM cannot be confirmed, but we suggest it could underlie her VT.

Wide intra- and interfamilial variation in MLS is recognized including carrier females with variants in HCCS or NDUFB11 (see Table 2) or terminal Xp deletions but no clinical features of MLS syndrome (van Rahden et al. 2015). There are several potential explanations for the wide phenotypic variation including somatic mosaicism; in their case of MLS (see Table 2) van Rahden and coworkers noted that the mutated base thymine was present in 42 sequence reads and the wild-type base cytosine in 84 , suggesting that the variant was present in mosaic state in lymphocytes. DNA isolated from fibroblasts was also suggestive of mosaicism 
Table 3. Catalog of variants reported in NDUFB11, with associated phenotypes

\begin{tabular}{|c|c|c|c|c|c|c|c|}
\hline & Case 1 & Case 2 & Case $3^{a}$ & Case $4^{a}$ & Case $5^{a}$ & Case 6 & Case 7 \\
\hline $\begin{array}{l}\text { Reported } \\
\text { diagnosis }\end{array}$ & $\begin{array}{l}\text { Histiocytoid } \\
\text { CM }\end{array}$ & $\begin{array}{l}\text { MLS } \\
\text { syndrome }\end{array}$ & MLS syndrome & Asymptomatic & $\begin{array}{l}\text { Terminated } \\
\text { pregnancy at } \\
\text { 24th wk } \\
\text { gestation }\end{array}$ & $\begin{array}{l}\text { Histiocytoid } \\
\text { CM }\end{array}$ & $\begin{array}{l}\text { Histiocytoid } \\
\text { CM }\end{array}$ \\
\hline Sex & Female & Female & Female & Female & Female & Female & Female \\
\hline $\begin{array}{l}\text { Cardiac } \\
\text { phenotype }\end{array}$ & $\begin{array}{l}\text { Histiocytoid } \\
\text { CM }\end{array}$ & $\begin{array}{l}\text { Histiocytoid } \\
\text { CM }\end{array}$ & $\begin{array}{l}\text { Developed dilated } \\
\text { cardiomyopathy } \\
\text { at } 2 \text { mo of age } \\
\text { requiring heart } \\
\text { transplant at } 6 \\
\text { mo of age }\end{array}$ & Nil reported & $\begin{array}{l}\text { Thickened } \\
\text { myocardium } \\
\text { Pericardial effusion }\end{array}$ & $\begin{array}{l}\text { Histiocytoid } \\
\text { CM }\end{array}$ & $\begin{array}{l}\text { Histiocytoid } \\
\text { CM }\end{array}$ \\
\hline $\begin{array}{l}\text { Eye } \\
\text { phenotype }\end{array}$ & $\begin{array}{l}\text { Intermittent } \\
\text { squint }\end{array}$ & $\begin{array}{l}\text { Lacrimal duct } \\
\text { atresia }\end{array}$ & $\begin{array}{l}\text { Myopia, nystagmus, } \\
\text { and strabismus }\end{array}$ & Nil reported & Nil reported & Nil reported & Nil reported \\
\hline $\begin{array}{l}\text { Skin } \\
\text { phenotype }\end{array}$ & Nil & $\begin{array}{l}\text { Linear skin } \\
\text { defects on } \\
\text { nose, chin, } \\
\text { and neck } \\
\text { present at } \\
\text { birth }\end{array}$ & $\begin{array}{l}\text { Linear and atrophic } \\
\text { hyperpigmented } \\
\text { streaks on face } \\
\text { and neck }\end{array}$ & Nil reported & Nil reported & Nil reported & Nil reported \\
\hline $\begin{array}{l}\text { Protein } \\
\quad \text { variant }^{c}\end{array}$ & p. $\left(\operatorname{Arg} 88^{*}\right)$ & p. $\left(\operatorname{Arg} 88^{*}\right)$ & p.(Arg134Serfs*3) & p.(Arg134Serfs*3) & p.(Arg134Serfs*3) & p. $\left(\operatorname{Trp} 85^{*}\right)$ & p.(Tyr108*) \\
\hline $\begin{array}{l}\text { Genomic } \\
\text { coordinate }^{d}\end{array}$ & 47002089 & 47002089 & 47001806 & 47001806 & 47001806 & 47002097 & 47002027 \\
\hline Exon & Exon 2 & Exon 2 & Exon 3 & Exon 3 & Exon 3 & Exon 2 & Exon 2 \\
\hline Status & De novo & De novo & $\begin{array}{l}\text { Inherited from } \\
\text { asymptomatic } \\
\text { mother }\end{array}$ & Unknown & $\begin{array}{l}\text { Inherited from } \\
\text { asymptomatic } \\
\text { mother }\end{array}$ & De novo & De novo \\
\hline $\begin{array}{l}\text { Other } \\
\text { phenotypic } \\
\text { features }\end{array}$ & $\begin{array}{l}\text { Bulbar palsy } \\
\text { Severe } \\
\text { feeding } \\
\text { difficulties }\end{array}$ & & $\begin{array}{l}\text { Seizures } \\
\text { Developmental } \\
\text { delay } \\
\text { Agenesis of the } \\
\text { corpus callosum } \\
\text { Severe muscular } \\
\text { hypotonia } \\
\text { Delayed dentition } \\
\text { Growth parameters } \\
\text { below the } 3 \text { rd } \\
\text { centile at } 15 / 12\end{array}$ & & $\begin{array}{l}\text { Intra-uterine } \\
\text { growth } \\
\text { retardation } \\
\text { Dysgenesis of the } \\
\text { corpus callosum } \\
\text { Small cerebellum } \\
\text { Connection } \\
\text { between a lateral } \\
\text { ventricle and the } \\
\text { cavum septum } \\
\text { pellucidum }\end{array}$ & & \\
\hline Reference & $\begin{array}{l}\text { Case } \\
\text { presented } \\
\text { here }\end{array}$ & Subject $1^{\mathrm{e}}$ & Subject $2^{e}$ & $\begin{array}{l}\text { Mother of } \\
\text { Subject } 2^{e}\end{array}$ & $\begin{array}{l}\text { Aborted fetus from } \\
\text { the mother of } \\
\text { subject } 2^{\mathrm{e}}\end{array}$ & GHC-G ${ }^{f}$ & $\mathrm{GHC}-\mathrm{T}^{f}$ \\
\hline
\end{tabular}

CM, cardiomyopathy; MLS, microphthalmia with linear skin defects.

aThree cases are from a single pedigree and they also have a heterozygous deletion of at least $70 \mathrm{~kb}$ at $2 \mathrm{p} 16.3$, containing part of NRXN1, which may have influenced the phenotype. Intragenic mutations and deletions of NRXN1 are enriched in cohorts with neurodevelopmental and autistic spectrum disorders. Incomplete penetrance is reported.

bNo evidence of histiocytoid CM reported, although further review of histology in light of current knowledge would be of interest.

'ENST00000276062.8.

${ }^{\mathrm{d}} \mathrm{GRCh} 37$ (hg19).

evan Rahden et al. 2015.

fShehata et al. 2015. 
(van Rahden et al. 2015). In addition, Shehata et al. (2015) note that in one of their cases with a nonsense NDUFB11 variant (case GHCG) a second nonsense variant was detected in cytochrome $b$, but only at a frequency of $20 \%$ and only in the cardiac tissue, possibly indicating a clonal selection of a somatic variant in the diseased heart. The authors suggest this is one of the potential avenues through which the expressivity of defects in MRC complex 1 activity might be regulated (Shehata et al. 2015). X-inactivation may also influence phenotypic variability as the majority of MLS-affected females have severe skewing of $X$ Chromosome inactivation suggesting that variants in causative $X$-linked gene(s) cause selective loss of cells in which the mutated X Chromosome is active (van Rahden et al. 2015). Other causes of phenotypic variability could include copy-number variation or common or rare modifier variants contributing to mitochondrial function (Shehata et al. 2015). Furthermore, phenotypic variability may reflect differing abilities of developing tissues and organs in embryonic cells to handle a defective MRC system (van Rahden et al. 2014).

\section{Conclusion}

We conclude that variants in NDUFB11 are an important cause of histiocytoid CM and report that histiocytoid CM and MLS, which are genetically heterogeneous, are allelic disorders. However, many histiocytoid CM cases remain unexplained by known genes, suggesting a heterogeneous genetic architecture with further contributing genes remaining to be discovered. Histiocytoid CM typically affects female infants $<2 \mathrm{yr}$ of age and the identification of NDUFB11, which is found on the chromosome band Xp11.23, as an underlying cause explains the large excess of affected females. Comparison of the phenotypes of histiocytoid $\mathrm{CM}$ and MLS shows both considerable overlap and features specific to each entity. Differences in phenotypic expression may be due to patterns of $\mathrm{X}$-inactivation, somatic mosaicism, presence of additional variants, environmental factors, or epigenetic factors. We suggest that individuals with MLS syndrome or variants or cytogenetic abnormalities involving NDUFB11, HCCS, or COX7B should be considered at risk for histiocytoid CM and screening for evidence of malignant arrhythmias and cardiomyopathy may be appropriate. Additional nuclear encoded or mtDNA genes within the MRC are good candidates for further causes of both histiocytoid CM and MLS syndrome.

\section{METHODS}

\section{Samples}

An infant with histiocytoid CM and both unaffected parents were recruited through the NIHR Cardiovascular Biomedical Research Unit at the Royal Brompton and Harefield NHS Foundation Trust. Four additional biologically unrelated histiocytoid cardiomyopathy probands were recruited via U.K. regional genetics services. Studies were performed according to institutional guidelines, with ethical approval.

\section{Whole-Exome Sequencing Using a Trio Approach}

The trio (of affected child and both unaffected parents) underwent WES using the Agilent SureSelect system (Human All Exon v4 + UTR kit) with Illumina sequencing (HiSeq 2500, 100-bp paired-end). Reads were aligned to the human reference genome (hg19) using Burrows-Wheeler alignment (BWA) (Li and Durbin 2009) v0.7.5, and variants were called using the Genome Analysis Toolkit (GATK) v2.8-1 software package (McKenna et al. 2010) according to GATK Best Practice recommendations (DePristo et al. 2011; Van der Auwera et al. 2013). In the affected child, mother, and father, WES generated 11.9 gigabases (Gb), $9.1 \mathrm{~Gb}$ and 10.4 Gb of data, respectively. The percentage callable was 99.4, 97.8, and 99.1, 
Table 4. Summary figures of coverage for WES in each sample of the family trio

\begin{tabular}{|c|c|c|c|c|c|c|c|c|c|c|}
\hline Sample & Total reads & $\begin{array}{l}\text { Mapped } \\
\text { reads }\end{array}$ & $\begin{array}{l}\text { Percentage } \\
\text { mapped }\end{array}$ & $\begin{array}{l}\text { Percentage } \\
\text { on target }\end{array}$ & $\begin{array}{c}\text { Bases } \\
10 \times\end{array}$ & $\begin{array}{c}\text { Bases } \\
20 \times\end{array}$ & $\begin{array}{c}\text { Bases } \\
30 \times\end{array}$ & $\begin{array}{c}\text { Percentage } \\
\text { callable }\end{array}$ & $\begin{array}{c}\text { Mean } \\
\text { coverage }\end{array}$ & $\begin{array}{l}\text { Median } \\
\text { coverage }\end{array}$ \\
\hline Affected child & $11,906,7512$ & $118,785,553$ & 99.8 & 81.7 & 97.8 & 93.4 & 87.6 & 99.4 & 113 & 89 \\
\hline Unaffected father & $91,775,652$ & $91,571,480$ & 99.8 & 69.4 & 91.9 & 80.5 & 70.0 & 97.8 & 74 & 53 \\
\hline Unaffected mother & $103,827,148$ & $103,582,562$ & 99.8 & 82.8 & 98.7 & 96.5 & 90.2 & 99.1 & 101 & 77 \\
\hline
\end{tabular}

The trio consists of a child affected with histiocytoid cardiomyopathy and both unaffected parents. Figures are for the coverage of the protein-coding target. Sequencing was undertaken using SureSelect Human All Exon V4 + UTR design (71 Mb) and the Illumina HiSeq 2500 platform.

WES, whole-exome sequencing.

respectively (see Table 4). Variants were prioritized using the open source software platform xBrowse (https://atgu.mgh.harvard.edu/xbrowse). Only variants that passed standard GATK filters, with genotype quality score $>20$, coverage $>20 x$, and allelic balance $>20$, were included in the analysis. We filtered for rare (minor allele frequency $[\mathrm{MAF}]<0.001$ in Exome Aggregation Consortium [ExAC], 1000 Genomes, and xBrowse reference samples) de novo variants, predicted to be protein altering (nonsense, frameshift, essential splice site, missense, and in-frame insertion or deletion) in the proband. All inheritance models were considered.

\section{Sanger Sequencing of NDUFB11}

The coding exons and intron-exon boundaries of NDUFB11 were amplified by polymerase chain reaction (PCR), and directly sequenced using the BigDye Terminator Cycle Sequencing Kit and an ABI3500 Genetic Analyzer (Applied Biosystems). Sequences were analyzed using Sequencher (v5.3) software. The coding sequence of all samples was fully covered in both directions.

\section{Sequencing Primers}

The sequencing primers were, for NDUFB11, F-TCCAGCCATGACTAGAGCTG, R-TCATC TCAGCTCCCCATTCC, and for FAM135A, F-GTTGTACTGCAGCCTTGTAATAAAC, RCAGCCTGAAGAACCATGACC.

\section{ADDITIONAL INFORMATION}

\section{Data Deposition and Access}

NDUFB11 (SCV000297804.1) and FAM135A (SCV000297805.1) variants have been submitted to ClinVar (htpp://www.ncbi.nlm.nih.gov/clinvar/). We do not have consent from patients to deposit complete sequencing data in a repository.

\section{Ethics Statement}

This study received research ethics committee approval (UK NRES Committee South Central - Hampshire B, reference 09/H0504/104) and all subjects (or parents where appropriate) provided written informed consent.

\section{Acknowledgments}

We thank the families presented in this report for their participation. 
Competing Interest Statement

The authors have declared no competing interest.

\section{Referees}

Gholson J. Lyon

Bahig M. Shehata

Received July 6, 2016; accepted in revised form October 20, 2016.

\section{Author Contributions}

G.R., P.J.R.B., S.A.C., and J.S.W. conceived and designed the study; G.R., J.T., F.R., T.H., M.A., R.J.B., A.W., S.W., S.J., and R.W. collected and analyzed data. G.R., P.J.R.B., S.A.C., and J.S.W. interpreted the data and wrote the paper. All authors have reviewed and approved the final manuscript.

\section{Funding}

This work was supported by the Academy of Medical Sciences, Wellcome Trust, British Heart Foundation, Arthritis Research UK, National Institute for Health Research (NIHR) Biomedical Research Unit in Cardiovascular Disease at Royal Brompton and Harefield NHS Foundation Trust and Imperial College London, Medical Research Council (UK), Foundation Leducq, a Health Innovation Challenge Fund (HICF) award from Wellcome Trust and Department of Health, The Lily Foundation, and the UK NHS Highly Specialised Commissioners.

\section{REFERENCES}

Al-Gazali LI, Mueller RF, Caine A, Dennis N, Antoniou A, Fitchett M, Insley J, Goodfellow PG, Hulten M. 1988. An $X X$ male and two $(X ; Y)$ females with linear skin defects and congenital microphthalmia: a new syndrome at Xp22.3. J Med Genet 25: 638-639.

Bird LM, Krous HF, Eichenfield LF, Swalwell Cl, Jones MC. 1994. Female infant with oncocytic cardiomyopathy and microphthalmia with linear skin defects (MLS): a clue to the pathogenesis of oncocytic cardiomyopathy? Am J Med Genet 53: 141-148.

DePristo MA, Banks E, Poplin R, Garimella KV, Maguire JR, Hartl C, Philippakis AA, del Angel G, Rivas MA, Hanna $M$, et al. 2011. A framework for variation discovery and genotyping using next-generation DNA sequencing data. Nat Genet 43: 491-498.

Ferrans VJ, McAllister HA Jr, Haese WH. 1976. Infantile cardiomyopathy with histiocytoid change in cardiac muscle cells. Report of six patients. Circulation 53: 708-719.

Gilbert-Barness E, Barness LA. 2006. Pathogenesis of cardiac conduction disorders in children genetic and histopathologic aspects. Am J Med Genet A 140: 1993-2006.

Happle R, Daniels O, Koopman RJ. 1993. MIDAS syndrome (microphthalmia, dermal aplasia, and sclerocornea): an X-linked phenotype distinct from Goltz syndrome. Am J Med Genet 47: 710-713.

Indrieri A, van Rahden VA, Tiranti V, Morleo M, laconis D, Tammaro R, D’Amato I, Conte I, Maystadt I, Demuth S, et al. 2012. Mutations in COX7B cause microphthalmia with linear skin lesions, an unconventional mitochondrial disease. Am J Hum Genet 91: 942-949.

Li H, Durbin R. 2009. Fast and accurate short read alignment with Burrows-Wheeler transform. Bioinformatics 25: $1754-1760$.

Malhotra V, Ferrans VJ, Virmani R. 1994. Infantile histiocytoid cardiomyopathy: three cases and literature review. Am Heart J 128: 1009-1021.

McKenna A, Hanna M, Banks E, Sivachenko A, Cibulskis K, Kernytsky A, Garimella K, Altshuler D, Gabriel S, Daly M, et al. 2010. The Genome Analysis Toolkit: a MapReduce framework for analyzing next-generation DNA sequencing data. Genome Res 20: 1297-1303.

Morleo M, Franco B. 1993. Microphthalmia with linear skin defects syndrome. In GeneReviews (ed. Pagon RA, et al.). University of Washington, Seattle, WA.

Shehata BM, Patterson K, Thomas JE, Scala-Barnett D, Dasu S, Robinson HB. 1998. Histiocytoid cardiomyopathy: three new cases and a review of the literature. Pediatr Dev Pathol 1: 56-69.

Shehata BM, Bouzyk M, Shulman SC, Tang W, Steelman CK, Davis GK, Moreno CS. 2011. Identification of candidate genes for histiocytoid cardiomyopathy $(\mathrm{HC})$ using whole genome expression analysis: analyzing material from the $\mathrm{HC}$ registry. Pediatr Dev Pathol 14: 370-377.

Shehata BM, Cundiff CA, Lee K, Sabharwal A, Lalwani MK, Davis AK, Agrawal V, Sivasubbu S, lannucci GJ, Gibson G. 2015. Exome sequencing of patients with histiocytoid cardiomyopathy reveals a de novo NDUFB11 mutation that plays a role in the pathogenesis of histiocytoid cardiomyopathy. Am J Med Genet A 167A: 2114-2121.

Vallance HD, Jeven G, Wallace DC, Brown MD. 2004. A case of sporadic infantile histiocytoid cardiomyopathy caused by the A8344G (MERRF) mitochondrial DNA mutation. Pediatr Cardiol 25: 538-540. 
Van der Auwera GA, Carneiro MO, Hartl C, Poplin R, Del Angel G, Levy-Moonshine A, Jordan T, Shakir K, Roazen D, Thibault J, et al. 2013. From FastQ data to high confidence variant calls: the Genome Analysis Toolkit best practices pipeline. Curr Protoc Bioinformatics 43: 11.10.1-11.10.33.

van Rahden VA, Rau I, Fuchs S, Kosyna FK, de Almeida HL Jr, Fryssira H, Isidor B, Jauch A, Joubert M, Lachmeijer AM, et al. 2014. Clinical spectrum of females with HCCS mutation: from no clinical signs to a neonatal lethal form of the microphthalmia with linear skin defects (MLS) syndrome. Orphanet J Rare Dis 9: 53.

van Rahden VA, Fernandez-Vizarra E, Alawi M, Brand K, Fellmann F, Horn D, Zeviani M, Kutsche K. 2015. Mutations in NDUFB11, encoding a complex I component of the mitochondrial respiratory chain, cause microphthalmia with linear skin defects syndrome. Am J Hum Genet 96: 640-650.

Wimplinger I, Morleo M, Rosenberger G, laconis D, Orth U, Meinecke P, Lerer I, Ballabio A, Gal A, Franco B, et al. 2006. Mutations of the mitochondrial holocytochrome c-type synthase in X-linked dominant microphthalmia with linear skin defects syndrome. Am J Hum Genet 79: 878-889. 


\section{COLD SPRING HARBOR Molecular Case Studies}

\section{Histiocytoid cardiomyopathy and microphthalmia with linear skin defects syndrome: phenotypes linked by truncating variants in NDUFB11}

Gillian Rea, Tessa Homfray, Jan Till, et al.

Cold Spring Harb Mol Case Stud 2017, 3: a001271 originally published online November 4, 2016 Access the most recent version at doi: $10.1101 / \mathrm{mcs} .0001271$

References This article cites 18 articles, 3 of which can be accessed free at: http://molecularcasestudies.cshlp.org/content/3/1/a001271.full.html\#ref-list-1

License This article is distributed under the terms of the Creative Commons Attribution License, which permits unrestricted reuse and redistribution provided that the original author and source are credited.

Email Alerting Receive free email alerts when new articles cite this article - sign up in the box at the Service top right corner of the article or click here. 